Jurnal Ilmu-Ilmu Peternakan 25 (2): 71 - 79

ISSN: 0852-3581

E-ISSN: 9772443D76DD3

CFakultas Peternakan UB, http://jiip.ub.ac.id/

\title{
Pengaruh lama istirahat terhadap karakteristik karkas dan kualitas fisik daging sapi Brahman Cross Steer
}

\author{
Mukhlas Agung Hidayat, Kuswati and Trinil Susilawati \\ Fakultas Peternakan Universitas Brawijaya Malang \\ Jl. Veteran Malang 65145 Jawa Timur \\ kuswati_bx44@yahoo.com
}

\begin{abstract}
The purposes of this study were determine the carcass characteristics and physical meat quality of Brahman Cross Steer on different rest periods. The experiment was conducted on June 2015 at Slaughter house Cianjur Arta Makmur Ltd. in the Cianjur District, West Java. The total number of cattle used in the study was 30 heads of Brahman Cross Steer treated for 18 hours lairage duration and 30 heads of Brahman Cross Steer treated for 3 hours lairage duration from Pasir Tengah feedloter Ltd (Holding Widodo Makmur Perkasa Ltd). The method used a case study. Data were analyzed using unpaired t test. The results showed that the carcass characteristics including slaughtered weight, hot carcass weight, chilled carcass weight and carcass weight loss percentage were not significantly different, while the dressing percentage for 18 hours lairage duration $(54.16 \pm 1.62 \%)$ and 3 hours lairage duration $(55.60 \pm 2.00 \%)$ was significantly different $(\mathrm{P}<0.05)$. Physical meat quality including cooking loss and drip loss was not significantly different, while $\mathrm{pH}$ on 18 hours lairage duration and 3 hours lairage duration was significantly different $(\mathrm{P}<0.05)$. The $\mathrm{pH}$ value of meat derived from cattle which treated for 18 hours lairage duration $(5.57 \pm 0.09)$ was higher than that of 3 hours lairage duration (5.42 \pm 0.11$)$ although it remained normal for $\mathrm{pH}$ (5.4-5.7). It was concluded that 18 and 3 hours lairage duration did not affect slaughtered weight, hot carcass weight, chilled carcass weight, and carcass weight loss, but affected the dressing percentage. In addition, the lairage duration did not affect the cooking loss and drip loss but affected the $\mathrm{pH}$ value of the meat.
\end{abstract}

Keywords: drip loss, cooking loss, fattening, $\mathrm{pH}$

\section{PENDAHULUAN}

Kebutuhan daging dalam negeri dipenuhi dari sapi lokal, sapi impor dan daging impor. Sapi yang banyak digemukan di Indonesia adalah sapi Brahman Cross (BX) yang diimpor dari Australia karena memiliki karkas yang lebih tinggi dibandingkan sapi lokal Indonesia (Kuswati et al, 2014). Bangsa (breed), umur, jenis kelamin, kondisi tubuh, penyakit, kelelahan (fatigue), resistensi terhadap stres dan penanganan sebelum dipotong akan berpengaruh terhadap kualitas daging pasca pemotongan.

Faktor-faktor sebelum pemotongan yang dapat mempengaruhi kualitas daging antara lain genetik, spesies, bangsa, tipe ternak, jenis kelamin, umur, pakan termasuk bahan aditif (hormon, antibiotik dan mineral) dan stres. Kondisi ternak sebelum dipotong sangat berpengaruh terhadap kualitas daging yang dihasilkan. Penanganan 
sebelum penyembelihan terutama istirahat ternak umumnya memiliki dampak yang besar terhadap kuantitas dan kualitas daging karena mempengaruhi metabolisme otot setelah penyembelihan. Menurut Ferguson et al.(2007), waktu istirahat standar yang dibutuhkan sapi sekitar 12-24 jam, sedangkan RPH PT. Cianjur Artha Makmur hanya mengistirahatkan ternak selama 3 jam. Menurut Soeparno (2009), istirahat ternak adalah penanganan ternak sebelum pemotongan dimana ternak didiamkan dalam kandang penampungan sementara dengan pemuasaan atau tanpa pemuasaan. Istirahat tanpa pemuasaan bertujuan agar ternak tidak stres ketika disembelih, sehingga dapat mengeluarkan darah sebanyak mungkin.

Ternak diistirahatkan selama 18 jam sebelum pemotongan merupakan salah satu cara menekan stres pada ternak. Tingkat stres akan mempengaruhi jumlah glikogen dalam otot yang digunakan sebagai cadangan energi otot saat proses rigormortis berlangsung. Glikogen yang rendah didalam otot menurunkan proses metabolisme setelah pemotongan sehingga $\mathrm{pH}$ daging lebih tinggi dari biasanya yang menyebabkan warna gelap pada jaringan otot dan menurunkan kualitas. Nilai pH juga berkaitan dengan daya ikat air daging dimana semakin menjauhi titik isoelektrik $\mathrm{pH}$ daging $(5,0-5,4)$, maka semakin meningkat pula daya mengikat airnya. Daya mengikat air tergambar dari sifat fisik daging diantaranya cooking loss dan drip loss. Cooking loss maupun drip loss yang terlalu tinggi tidak dikehendaki dalam produksi daging karena dapat menurunkan nilai ekonomis daging. Selain itu, penanganan ternak sebelum pemotongan juga dapat mempengaruhi persentase penyusutan karkas selama pelayuan yang tergambar dari bobot karkas segar dan bobot karkas layu.
Semakin tinggi penyusutan karkas, maka produksi karkasnya semakin rendah.

Berdasarkan uraian diatas, maka penelitian bertujuan untuk mengetahui karakteristik karkas dan kualitas fisik daging sapi Brahman Cross Steer pada lama istirahat yang berbeda.

\section{MATERI DAN METODE}

Metode yang digunakan dalam penelitian ini adalah studi kasus di RPH Cianjur Arta Makmur. Pengambilan sampel dilakukan dengan random sampling pada bulan Juni 2015. Random sampling adalah salah satu metode nonprobability sampling technique yang memungkinkan peneliti untuk menentukan sampel secara acak dan dapat mewakili populasi. Metode random sampling digunakan dalam penelitian ini karena data populasi bersifat homogen, sehingga data sampel yang terpilih dapat mewakili populasi.

Materi penelitian adalah sapi Brahman Cross Steer sebanyak 60 ekor terdiri dari 30 ekor sapi Brahman Cross Steer yang diistirahatkan selama 18 jam dan 30 ekor sapi Brahman Cross Steer yang diistirahatkan selama 3 jam dengan kisaran umur 1,5-2 tahun. Peralatan yang digunakan adalah timbangan ternak digital "Great Scale" kapasitas $1500 \mathrm{~kg}$ dengan ketelitian $1 \mathrm{~kg}$ untuk menimbang bobot potong istirahat, restraining box, alat stunning bertenaga angin dengan kapasitas tekanan 6-12 bar, pisau bleeding, pisau skinning, katrol, brisket saw, carcass splitting saw, $\mathrm{pH}$ meter digital, timbangan analitik, oven, timbangan karkas (carcass scale) dengan ketelitian $0,5 \mathrm{~kg}$, mesin vacuum pack, plastik vacuum, termometer dan refrigerator bersuhu $4{ }^{0} \mathrm{C}$.

Variabel yang digunakan dalam penelitian ini meliputi bobot potong yaitu bobot hidup sapi yang ditimbang saat akan dipotong, bobot karkas segar, persentase karkas, bobot karkas layu yaitu 
bobot karkas setelah dilayukan, persentase penyusutan karkas, $\mathrm{pH}$ daging, drip loss dan cooking loss. Persentase penyusutan karkas didapatkan dengan cara mengurangi bobot karkas segar dengan bobot karkas layu. Rumus persentase penyusutan karkas sebagai berikut :

$\%$ penyusutan karkas $=\frac{A-B}{A} \chi 100 \%$

Keterangan :

A : Bobot karkas segar

B : Bobot karkas layu

Pemeriksaan cooking loss dilakukan melalui tiga tahap yaitu tahap penimbangan contoh, pemasakan dan tahap pengukuran. Contoh daging ditimbang (A gram) kemudian dimasukkan kedalam kantong plastik tahan panas. Daging tersebut dipanaskan dalam air dengan suhu $75^{\circ} \mathrm{C}$ selama 50 menit selanjutnya ditimbang kembali (B gram). Contoh daging dikeluarkan dan didinginkan pada suhu $1-5^{\circ} \mathrm{C}$. Salakova et al (2009) menyebutkan bahwa pengukuran nilai cooking loss dilakukan berdasarkan rumus sebagai berikut:

$\%$ cooking loss $=\frac{A-B}{A} \times 100 \%$

Keterangan:

$\mathrm{A}=$ Berat daging sebelum perlakuan (gram)

$\mathrm{B}=$ Berat daging setelah perlakuan (gram)

Pemeriksaan drip loss dilakukan melalui 3 tahap yaitu tahap penimbangan contoh, penggantungan sampel dan tahap pengukuran. Contoh daging ditimbang (A gram) kemudian digantung dengan tali khusus dan dimasukkan dalam kantong plastik tanpa menyentuh permukaan plastik. Selanjutnya disimpan didalam refrigerator bersuhu $4{ }^{0} \mathrm{C}$ selama 48 jam. Setelah 48 jam ditimbang kembali (B gram). Soeparno (2009) menjelaskan bahwa pengukuran nilai drip loss dilakukan berdasarkan rumus sebagai berikut:

$\%$ drip loss $=\frac{A-B}{A} \times 100 \%$

Keterangan:

$\mathrm{A}=$ Berat daging sebelum perlakuan (gram)

$\mathrm{B}=$ Berat daging setelah perlakuan (gram)

\section{Analisa data}

Data dianalisis menggunakan uji "t-tidak berpasangan" untuk mengetahui pengaruh lama istirahat terhadap karakteristik karkas dan kualitas fisik daging. Rumus yang digunakan adalah :

$$
\mathrm{t}_{\text {hitung }}=\frac{\left\{\left|\bar{x}_{a}-\bar{x}_{b}\right|\right\}}{\sqrt{s_{a b}^{2}\left(\frac{1}{n_{a}}+\frac{1}{n_{b}}\right)}}
$$

Keterangan:

$\bar{x}_{a}=$ Rata-rata sapi dengan lama istirahat 18 jam

$\bar{x}_{b}=$ Rata-rata sapi dengan lama istirahat 3 jam

$S_{a b}^{2}=$ Ragam gabungan dari kelompok dengan lama istirahat 18 jam dan 3 jam

$\mathrm{n}_{\mathrm{a}}=$ Jumlah sampel sapi dengan lama istirahat 18 jam

$\mathrm{n}_{\mathrm{b}}=$ Jumlah sampel sapi dengan lama istirahat 3 jam

Dimana $S_{a b}^{2}$ diperoleh dari rumus :

$$
S_{a b}^{2}=\frac{\left(n_{a}-1\right)\left(n_{a}\right)+\left(n_{b}-1\right)\left(s_{b}\right)}{\left\{\left(n_{a}-1\right)+\left(n_{b}-1\right)\right\}}
$$

Keterangan :

$\mathrm{S}_{\mathrm{a}}=$ Ragam dari kelompok sapi dengan lama istirahat 18 jam

$\mathrm{S}_{\mathrm{b}}=$ Ragam dari kelompok sapi dengan lama istirahat 3 jam 
HASIL DAN PEMBAHASAN

\section{Karakteristik karkas sapi Brahman Cross Steer pada lama istirahat 18 jam dan 3 jam}

Rata-rata bobot potong, bobot karkas segar, bobot karkas layu, persentase karkas sapi Brahman Cross Steer pada lama istirahat yang berbeda ditunjukkan pada Tabel 1. Hasil analisis menunjukkan bobot potong sapi Brahman Cross Steer yang diistirahatkan selama 18 jam dan 3 jam tidak berbeda nyata $(\mathrm{P}<0,05)$. Rata-rata bobot potong sapi dengan lama istirahat 18 jam lebih tinggi $(517,17 \pm 49,38 \mathrm{~kg})$ dibandingkan lama istirahat 3 jam $(506,47 \pm 39,89 \mathrm{~kg})$.

Tabel 1. Rataan bobot potong, bobot karkas, persentase karkas dan penyusutan karkas sapi Brahman Cross Steer pada lama istirahat yang berbeda

\begin{tabular}{cccc}
\hline No & Variabel & Lama istirahat (jam) & Rata-rata \pm sd \\
\hline 1. & Bobot potong $(\mathrm{Kg})$ & 18 & $517,17 \pm 49,38$ \\
& & 3 & $506,47 \pm 39,89$ \\
& & Rataan & $511,82 \pm 44,83$ \\
\hline 2. & Bobot karkas segar $(\mathrm{Kg})$ & 18 & $279,86 \pm 25,33$ \\
& & 3 & $281,38 \pm 21,77$ \\
& & Rataan & $280,62 \pm 23,43$ \\
\hline 3. & Bobot karkas layu (Kg) & 18 & $274,9 \pm 24,86$ \\
& & 3 & $276,08 \pm 21,30$ \\
& & Rataan & $275,43 \pm 22,96$ \\
\hline 4. & Persentase karkas $(\%)$ & 18 & $54,16 \pm 1,62^{\mathrm{a}}$ \\
& & 3 & $55,60 \pm 2,00^{\mathrm{b}}$ \\
& & Rataan & $54,88 \pm 1,95$ \\
\hline 5. & Penyusutan karkas $(\%)$ & 18 & $1,81 \pm 0,26$ \\
& & 3 & $1,88 \pm 0,27$ \\
& & Rataan & $1,85 \pm 0,26$ \\
\hline
\end{tabular}

Keterangan : Superskrip yang berbeda pada kolom yang sama menunjukkan perbedaan nyata $(\mathrm{P}<0,05)$

Hasil analisis bobot potong yang tidak berbeda nyata dapat disebabkan karena tidak dilakukan pemuasaan selama sapi diistirahatkan. Pemuasaan ternak sebelum pemotongan dapat mengurangi isi saluran pencernaan sehingga berdampak pada penurunan bobot potong. Hafid dan Rugayah (2009) menyebutkan bahwa semakin lama periode pemuasaan yang diterapkan maka penurunan bobot hidup juga semakin besar. Hal ini disebabkan oleh proses urinasi dan defekasi yang lebih banyak yang pada akhirnya berimplikasi pada bobot hidup yang semakin berkurang.
Tabel 1 menunjukkan bahwa bobot karkas segar dan bobot karkas layu pada lama istirahat 18 jam dan 3 jam berbeda tidak nyata. Bobot karkas segar dan layu dipengaruhi oleh bobot potong dimana semakin tinggi bobot potong, maka bobot karkasnya juga semakin tinggi. Rata-rata bobot karkas segar pada lama istirahat 18 jam dan 3 jam berturut-turut $279,86 \pm 25,33 \mathrm{~kg}$ dan $281,38 \pm 21,77 \mathrm{~kg}$ dengan bobot potong berturut-turut $517,17 \pm 49,38 \mathrm{~kg}$ dan $506,47 \pm 39,89 \mathrm{~kg}$. Hasil analisis tersebut sesuai dengan pernyataan Choi et al. (2010) bahwa bobot karkas sangat dipengaruhi oleh bobot potong dimana semakin tinggi bobot potong maka 
bobot karkas juga akan bertambah. Bobot karkas sebagian besar dipengaruhi oleh bobot otot atau daging. Lama istirahat tidak memiliki pengaruh terhadap bobot karkas segar karena proses istirahat bertujuan untuk menurunkan tingkat stress ternak selama proses transportasi ke RPH dan tidak mempengaruhi struktur serta komposisi karkas. Komposisi karkas secara umum adalah daging, tulang, lemak dan tendon. Bobot karkas layu lebih rendah dibandingkan bobot karkas segar karena selama proses pelayuan terjadi penyusutan bobot. Penyusutan terjadi akibat keluarnya cairan yang dinamakan drip serta penguapan air yang terjadi selama proses pelayuan. Menurut Soeparno (2009), drip adalah cairan daging yang keluar atau eksudasi cairan beserta nutrien daging yang larut dan hilang selama proses pelayuan.

Tabel 1 juga menunjukkan bahwa persentase karkas pada lama istirahat 18 jam dan 3 jam berbeda nyata $(\mathrm{P}<0,05)$. Persentase karkas pada lama istirahat 3 jam lebih tinggi $(55,60$ $\pm 2,00 \mathrm{~kg}$ ) dibandingkan pada lama istirahat 18 jam $(54,16 \pm 1,62 \mathrm{~kg})$. Perbedaan persentase karkas tersebut disebabkan karena isi saluran pencernaan sapi pada lama istirahat 3 jam lebih sedikit, sedangkan istirahat selama 18 jam dilakukan tanpa proses pemuasaan sehingga isi saluran pencernaan cenderung lebih banyak dari pada sapi yang diistirahatkan selama 3 jam dengan pemuasaan. Persentase karkas sangat dipengaruhi oleh bobot potong, bobot karkas dan bobot non karkas. Tingginya bobot karkas tidak selalu diikuti dengan tingginya persentase karkas karena ada perbedaan isi saluran pencernaan. Hal tersebut sesuai dengan pernyataan Hafid (2002) yang menyatakan bahwa perbedaan persentase karkas selain dipengaruhi oleh bobot karkas, juga dipengaruhi oleh isi saluran pencernaan. Sapi yang tidak dipuasakan sebelum dipotong tidak mengalami penyusutan bobot potong, sehingga persentase karkasnya lebih rendah.

Penyusutan karkas merupakan berkurangnya bobot karkas selama proses pelayuan. Penyusutan karkas sapi pada lama istirahat 18 jam dan 3 jam tidak berbeda nyata. Bobot karkas sapi yang diistirahatkan selama 18 dan 3 jam mengalami susut berturut turut 1,81 $\pm 0,26 \%$ dan $1,88 \pm 0,27 \%$. Data tersebut lebih rendah dibandingkan dengan hasil penelitian Sunarlim dan Hadi (2001) dimana susut bobot karkas pada pelayuan selama sehari (24 jam) pada suhu $4{ }^{\circ} \mathrm{C}$ sebesar 2,90\%. Perbedaan tersebut diduga karena perbedaan lama waktu pelayuan dan suhu. Pada penelitian ini proses pelayuan dilakukan selama 18 jam. Semakin lama proses pelayuan dapat meningkatkan persentase penyusutan karkas. Sunarlim dan Hadi (2001) menemukan bahwa persentase penyusutan karkas terbanyak ditemukan pada karkas yang dilayukan pada suhu $4{ }^{\circ} \mathrm{C}$ selama seminggu $(13,58 \%)$ yang berbeda nyata dibandingkan dengan susut bobot karkas dengan pelayuan pada suhu $4{ }^{\circ} \mathrm{C}$ selama sehari $(2,90 \%)$.

Lama istirahat 18 dan 3 jam pada penelitian ini tidak berpengaruh nyata terhadap penyusutan karkas karena proses transportasi dari supplier sapi ke $R P H$ hanya memerlukan waktu yang singkat. Semakin singkat proses transportasi dapat menekan tingkat stres ternak. Menurut Adzitey (2011), ternak dapat terpapar oleh stres akibat lingkungan seperti panas, kelembaban, suara dan kepadatan selama proses transportasi. Stres selama transportasi merupakan faktor yang dapat mempengaruhi penyusutan karkas.

Penyusutan karkas pada lama istirahat 18 jam lebih rendah 
dibandingkan pada lama istirahat 3 jam. Semakin rendah penyusutan karkas dapat meningkatkan nilai produksi suatu karkas. Data kerugian berdasarkan hitungan produksi ditunjukkan pada Tabel 2.

Tabel 2. Selisih produksi karkas per bulan berdasarkan penyusutan karkas pada lama istirahat yang berbeda

\begin{tabular}{|c|c|c|c|}
\hline & $\begin{array}{l}\text { Lama istira- } \\
\text { hat } 18 \text { jam }\end{array}$ & $\begin{array}{l}\text { Lama istira- } \\
\text { hat } 3 \text { jam }\end{array}$ & \\
\hline $\begin{array}{l}\text { Jumlah pemotongan per bulan } \\
\text { (ekor) }\end{array}$ & \multicolumn{2}{|c|}{$\begin{array}{c}800 \text { (pemotongan } 40 \text { ekor per } \\
\text { hari) }\end{array}$} & $\begin{array}{l}\text { Selisih total pe- } \\
\text { nyusutan karkas }\end{array}$ \\
\hline Rataan bobot karkas (Kg) & \multicolumn{2}{|c|}{$280,62 \pm 23,43$} & lama istirahat 18 \\
\hline Rataan penyusutan karkas (\%) & 1,81 & 1,88 & jam dan 3 jam se- \\
\hline Produksi karkas per bulan $(\mathrm{Kg})$ & \multicolumn{2}{|c|}{224.496} & 15714 \\
\hline $\begin{array}{l}\text { Penyusutan karkas per bulan } \\
(\mathrm{Kg})\end{array}$ & 4063,38 & 4220,52 & \\
\hline
\end{tabular}

Tabel 2 menunjukkan selisih produksi karkas pada lama istirahat 18 jam dan 3 jam sebesar 157,14 kg/bulan dengan jumlah pemotongan sebanyak 800 ekor/bulan. Selisih produksi antara lama istirahat 18 jam dan 3 jam tersebut setara dengan bobot karkas 0,56 ekor sapi.

\section{Kualitas fisik daging sapi Brahman Cross Steer pada lama istirahat 18 jam dan 3 jam}

Rata-rata $\mathrm{pH}$, cooking loss dan drip loss daging sapi Brahman Cross Steer pada lama istirahat 18 dan 3 jam ditunjukkan pada Tabel 3.

Tabel 3. Rataan $\mathrm{pH}$, cooking loss dan drip loss daging sapi Brahman Cross Steer pada lama istirahat yang berbeda

\begin{tabular}{cccc}
\hline No & Variabel & Lama istirahat (jam) & Rata-rata \pm sd \\
\hline 1 & pH daging & 18 & $5,57 \pm 0,09^{\mathrm{a}}$ \\
& & 3 & $5,42 \pm 0,11^{\mathrm{b}}$ \\
& & Rataan & $5,49 \pm 0,13$ \\
\hline 2 & Cooking loss $(\%)$ & 18 & $37,56 \pm 1,86$ \\
& & 3 & $38,00 \pm 3,78$ \\
& & Rataan & $37,78 \pm 2,96$ \\
\hline 3 & Drip loss $(\%)$ & 18 & $9,27 \pm 2,86$ \\
& & 3 & $9,64 \pm 1,81$ \\
& & Rataan & $9,45 \pm 2,38$ \\
\hline
\end{tabular}

$\overline{\text { Keterangan : Superskrip yang berbeda pada kolom yang sama menunjukkan perbedaan }}$ nyata $(\mathrm{P}<0,05)$

Tabel 3 menunjukkan nilai $\mathrm{pH}$ daging pada lama istirahat 18 jam lebih tinggi $(5,57 \pm 0,09)$ dibandingkan pada lama istirahat 3 jam $(5,42 \pm 0,11)$ tetapi masih dalam batas $\mathrm{pH}$ normal daging setelah pelayuan. Menurut Aberle et al
(2001), nilai $\mathrm{pH}$ otot setelah ternak mati akan menurun dari 7,4 hingga mencapai $\mathrm{pH}$ 5,3-5,7. Hal ini dikarenakan ternak sebelum dipotong memiliki cadangan glikogen dalam otot yang cukup sehingga asam laktat yang dihasilkan 
setelah ternak disembelih cukup untuk menurunkan $\mathrm{pH}$ daging secara optimal. Nilai $\mathrm{pH}$ daging yang tinggi akan menyebabkan daging berwarna gelap. Mounier et al (2006) menyatakan bahwa kondisi stres dapat meningkatkan konsentrasi kortisol darah dan disertai dengan deplesi glikogen pada otot. Hal tersebut menyebabkan penurunan produksi asam laktat posmortem dan $\mathrm{pH}$ daging yang tetap tinggi. Nilai $\mathrm{pH}$ daging pada lama istirahat 18 jam dan 3 jam tergolong normal karena tingkat stres ternak sebelum dipotong rendah. Hal ini dikarenakan jarak antara tempat asal ternak ke RPH relatif dekat. Waktu istirahat untuk makan dan minum dibutuhkan oleh ternak untuk memulihkan kondisi akibat proses transportasi. Sapi yang ditransportasikan selama kurang dari enam jam dapat diistirahatkan minimal selama dua jam sebelum penyembelihan (Ferguson et al. 2007).

Hasil analisis cooking loss menunjukkan sapi Brahman Cross Steer yang diistirahatkan selama 18 jam dan 3 jam tidak berbeda nyata. Rata-rata cooking loss dengan lama istirahat 18 jam lebih rendah $(37,56 \pm 1,86 \%)$ dibandingkan pada lama istirahat 3 jam $(38,00 \pm 3,78 \%)$. Namun, persentase cooking loss masih dalam batas normal.

Nilai susut masak daging sapi berdasarkan penelitian Brahmantiyo (2000) berkisar antara 37,53-38,34\%, sedangkan penelitian Yanti dkk (2008) menunjukkan nilai susut masak daging sapi 42,77-44,65\%. Nilai cooking loss yang diperoleh masih termasuk dalam kisaran normal. Cooking loss pada lama istirahat 3 jam memiliki persentase yang lebih tinggi dari lama istirahat 18 jam. Semakin tinggi cooking loss, maka kualitas daging semakin rendah. Menurut Soeparno (2009), cooking loss dipengaruhi oleh waktu setelah pemotongan.
Perubahan cooking loss disebabkan terjadinya penurunan $\mathrm{pH}$ daging postmortem yang mengakibatkan banyak protein miofibriller yang rusak, sehinggga diikuti dengan kehilangan kemampuan protein untuk mengikat air yang pada akhirnya cooking loss semakin besar.

Hasil penelitian pada uji drip loss menunjukkan bahwa daging pada lama istirahat 18 jam dan 3 jam tidak berbeda nyata. Drip loss merupakan salah satu parameter pengukuran kualitas daging selain cooking loss. Drip loss adalah penyusutan bobot daging selama proses penyimpanan karena adanya cairan dalam daging yang keluar pada proses tersebut. Drip loss pada lama istirahat 18 jam dan 3 jam berturut-turut sebesar 9,27 $\pm 2,86 \%$ dan 9,64 $\pm 1,81 \%$. Selain dipengaruhi oleh lamanya waktu penyimpanan daging, drip loss juga dipengaruhi oleh tingkat stres ternak sebelum dipotong. Penanganan ternak sebelum pemotongan diantaranya istirahat ternak dan tipe pemotogan tanpa pemingsanan atau dengan pemingsanan. Proses penanganan ternak dengan restraining box menyebabkan ternak lebih tenang pada saat pemotongan. Sedangkan pada ternak yang tidak menggunakan restraining box, ternak lebih banyak bergerak sehingga ternak mengalami stres. Soeparno (2009) menyebutkan bahwa stres sebelum pemotongan disebabkan oleh ketakutan, terluka dan gerakan yang berlebihan.

Daya ikat air daging merupakan kemampuan daging dalam mempertahankan kandungan air dalam daging yang terlihat dari besarnya cooking loss dan drip loss. Semakin tinggi daya ikat air daging, semakin rendah air bebas yang keluar dari daging. Hal ini sesuai dengan pernyataan Shanks et al (2002) yang menyebutkan bahwa besarnya susut masak daging dipengaruhi oleh banyaknya air yang keluar dari daging. Daya mengikat air dipengaruhi oleh $\mathrm{pH}$ 
akhir daging. Lawrie (2003) menyebutkan bahwa tingkat penurunan $\mathrm{pH}$ postmortem berpengaruh terhadap daya mengikat air. Apabila nilai $\mathrm{pH}$ lebih tinggi atau lebih rendah dari titik isoelektrik daging $(5,0-5,1)$ maka nilai daya ikat air daging akan tinggi. Apabila ternak diistirahatkan sebelum dipotong, maka jumlah glikogen didalam otot dapat dipertahankan tinggi. Setelah ternak dipotong, glikogen didalam otot akan berubah menjadi asam laktat dalam keadaan anaerob dan nilai $\mathrm{pH}$ ultimat akan tercapai apabila glikogen otot menjadi habis, sehingga nilai daya mengikat air daging meningkat. Hal tersebut sesuai dengan nilai $\mathrm{pH}$ pada lama istirahat 18 jam yang lebih tinggi daripada lama istirahat 3 jam. Penurunan $\mathrm{pH}$ pada lama istirahat 18 jam lebih lambat dikarenakan cadangan glikogen dalam otot lebih tinggi. Nilai $\mathrm{pH}$ lama istirahat 18 jam lebih tinggi sehingga mempengaruhi daya ikat air yang menyebabkan cooking loss dan drip loss lebih rendah dari lama istirahat 3 jam. Nilai cooking loss dan drip loss yang lebih rendah merupakan indikator peningkatan kualitas fisik daging.

\section{KESIMPULAN}

Hasil penelitian menyimpulkan bahwa lama istirahat 18 dan 3 jam tidak mempengaruhi bobot potong, bobot karkas segar, bobot karkas layu dan persentase penyusutan karkas tetapi berpengaruh terhadap persentase karkas. Selain itu, lama istirahat tidak berpengaruh terhadap cooking loss dan drip loss tetapi berpengaruh nyata terhadap nilai $\mathrm{pH}$ daging meskipun masih dalam rentang $\mathrm{pH}$ daging yang normal $(5,4-$ $5,7)$.

DAFTAR PUSTAKA

Adzitey, F. 2011. Minireview effect of pre slaughter animal handling on carcass and meat quality. Int Food Res J. 18: 485-491.

Brahmantiyo, B. 2000. Sifat fisik dan kimia daging sapi Brahman Cross, Angus dan Murray Grey. Media Veteriner. 7(2): 9-11.

Choi, B., K. Ryu, J. Bong, J. Lee, Y. Choy, S. Son, O. Han and M. Baik. 2010. Comparison of steroid hormone concentrations and mRNA levels of steroidreceptor genes in longissimus dorsi muscle and subcutaneous fat between bulls and steers and association with carcass traits in Korean cattle. Liv. Sci. 131: 218226.

Ferguson D. M., F. D. Shaw and J. L. Stark. 2007. Effect of reduced lairage duration on beef quality. Aus J Exp Agric. 47: 770-773.

Hafid, H. 2002. Pengaruh pertumbuhan kompensasi terhadap efisiensi pertumbuhan sapi Brahman Cross Kebiri pada penggemukan feedlot. Jurnal Ilmu-Ilmu Pertanian Agroland. 9 (2): 179-185.

Hafid, H dan N. Rugayah. 2009. Persentase karkas sapi Bali pada berbagai berat badan dan lama pemuasaan sebelum pemotongan. Teknologi Peternakan dan Veteriner. 1(1): 77-85.

Kuswati, Kusmartono, T. Susilawati, D. Rosyidi dan A. Agus. 2014. Carcass characteristics of Brahman Cross breed cattle in Indonesian feedlot. IOSR Journal of Agriculture and Veterinary Science. 7(4): 19-24.

Lawrie, R. A. 2003. Ilmu daging. Penerjemah: Aminuddin Parakkasi. Universitas Indonesia Press. Jakarta.

Mounier L., H. Dubroeucq, S. Andanson and I. Veissier. 2006. Variations in meat $\mathrm{pH}$ of beef bulls in relation to conditions of 
transfer to slaughter and previous history of the animals. J Anim Sci. 84:1567-1576.

Salakova A., E. Strakova, V. Valkova, H. Buchtova and I. Steinhauserova. 2009. Quality indicators of chicken broiler raw and cooked meat depending on their sex. Acta Vet Brno. 78:497-504.

Shanks, B. C., D. M. Wolf and R. J. Maddock. 2002. Technical note: The effect of freezing on warner bratzler shear force values of beef longissimuss steak across several postmortem aging periods. J. Anim.Sci. 80: 21222125.
Soeparno. 2009. Ilmu dan teknologi daging. Gadjah Mada University Press. Yogyakarta.

Sunarlim, R dan S. Hadi. 2001. Pelayuan pada suhu kamar dan suhu dingin terhadap mutu daging dan susut bobot karkas domba. Jurnal Ilmu Ternak Dan Veteriner. (1) : 51-58.

Yanti, H., Hidayati dan Elfawati. 2008. Kualitas daging sapi dengan kemasan plastik PE (Polyethylen) dan plastik PP (Polypropylen) di Pasar Arengka Kota Pekanbaru. J. Peternakan. 5(1): 2227. 